\title{
Generic Imatinib Mesylate is as Effective as Original Glivec in the Clinical Management of CML
}

\author{
Umit Y. MALKAN ${ }^{1}$, Salih AKSU' ${ }^{1}$, Sude H. AKTIMUR ${ }^{2}$, Hilmi ATAY², Ozlen BEKTAS ${ }^{3}$, \\ Yahya BUYUKASIK ${ }^{1}$, Haluk DEMIROGLU ${ }^{1}$, Eylem ELIACIK ${ }^{1}$, Mert ESME ${ }^{4}$, \\ Abdullah HACIHANEFIOGLU ${ }^{5}$, Gursel GUNES ${ }^{1}$, Hakan GÖKER ${ }^{1}$, Sema KARAKUS ${ }^{6}$, \\ Saadettin KILICKAP ${ }^{7}$, Ebru KOCA ${ }^{6}$, Osman I. OZCEBE ${ }^{1}$, Nilgun SAYINALP ${ }^{1}$, Pmar TARKUN ${ }^{5}$, \\ Mehmet TURGUT ${ }^{2}$, Ibrahim C. HAZNEDAROGLU ${ }^{1 *}$
}

\footnotetext{
${ }^{1}$ Hacettepe University, Faculty of Medicine, Department of Hematology, Ankara

${ }^{2}$ Ondokuz Mayis University, Faculty of Medicine, Department of Hematology, Samsun

${ }^{3}$ Konya Research and Training Hospital, Department of Hematology, Konya

${ }^{4}$ Hacettepe University, Faculty of Medicine, Department of Internal Medicine, Ankara

${ }^{5}$ Kocaeli University, Faculty of Medicine, Department of Hematology, Kocaeli

${ }^{6}$ Baskent University, Faculty of Medicine, Department of Hematology, Ankara

${ }^{7}$ Hacettepe University, Faculty of Medicine, Department of Oncology, Ankara, TURKEY

* On behalf of Turkish CML Study Group, TURKEY
}

\begin{abstract}
Unsustainable drug prices in chronic myeloid leukemia (CML) and cancer may be causing harm to patients. The aim of this multicenter study is to assess the efficacy of generic imatinib mesylate (IM) over Glivec in terms of hematological, cytogenetic, and molecular responses in CML. The data of $120 \mathrm{CML}$ patients, who were treated with generic or original form of IM, were obtained from six different hematology clinics in Turkey between the years of 2009-2014 and analyzed retrospectively. Initial evaluation revealed that only one patient who was using original molecule switched to second generation tyrosine kinase inhibitor (TKI). In this period, hematological response(HR) was observed in $99.2 \%$ of the patients, cytogenetic response (CR) was observed in $88.7 \%$ of the patients (47 of 53), and molecular response (MR) was observed in $75 \%$ of the patients. Clinicians had a tendency to prefer generic molecules in each sequent visit, and this switch rate was statistically significant $(p<0.001) .11$ patients, who were using original molecules during all cohorts, switched to second generation TKI. On the other hand, only one patient, who was using generic molecules, switched to second generation TKI. Our paper may help to clarify the doubts about the efficacy of generic IM compared to original molecule. In our study we did not find any significant difference in HR, CR, and MR for original and generic drugs in each visit. Herein, we find low rates of need to switch to second generation TKIs with generic IM and no difference in treatment responses between generic and original molecules that confirms the non-inferiority of generic TKIs over original molecules.
\end{abstract}

Keywords: Generic, Imatinib, Glivec, Chronic Myeloid Leukemia 
International Journal of Hematology and Oncology

ÖZET

Jenerik İmatinib Mesilat KML'nin Klinik Yönetiminde Orijinal Glivec Kadar Etkilidir

Kronik myeloid lösemi (KML)'de ve diğer kanserlerde sürdürülemez ilaç fiyatları hastalara zarar verebilir.Biz bu çok merkezli çalışmada,KML'de jenerik imatinib mesilat (IM) ile Glivec'i hematolojik,sitogenetik ve moleküler yanıt açısından kıyaslamayı amaçladık. IM'ın jenerik ya da original formu ile 2009-2014 yılları arasında Türkiye'deki 6 değişik hematoloji kliniğinde tedavi edilen 120 KML hastasının verileri geriye dönük olarak araştııldı. Illk incelemede,orijinal molekül kullanan yalnızca bir hastanın ikinci jenerasyon tirozin kinaz inhibitörü (TKI)'ne geçtiği anlaşıldı. Bu periyodda,hastaların \%99.2'sinde hematolojik yanıt (HR),\%88.7'sinde(53 hastanın 47'si) sitogenetik yanıt (CR) ve \%75'inde moleküler yanıt (MR)saptandı.Klinisyenlerin her vizit sonrası artan oranda jenerik moleküle geçme eğilimleri gözlendi ve bu jenerik ilaca geçme oranı istatistiksel olarak anlamlıydı(p< 0.001).Tüm kohortlarda, orijinal molekül kullanan 11 hastanın ilacı ikinci jenerasyon TKl'a değiştirildi. Diğer yandan, jenerik molekül kullanan sadece bir hastanın ilacı ikinci jenrasyon TKl'a değiştirildi.Bu çalışma,jenerik IM'ın orijinal molekülle kıyaslanan etkinliği hakkındaki şüpheleri gidermeye yardımcı olabilir.Bizim çalışmamızda, orijinal ve jenerik ilaçlar arasında her vizitte tespit edilen HR,CR ve MR oranlarında farkllık saptanmamştır.Bu çalışmada jenerik IM kullanan hastalarda ikinci jenerasyon TKI'lerine geçme intiyacı düşük sıklıkta saptanmış olup aynı zamanda jenerik ve orijinal moleküller arasında tedavi yanıtı açısından farkılık saptanmamıştır.Sonuç olarak, bizim çalışmamızdaki bulgular jenerik TKI'lerinin orijinal molekül ile kıyaslandığında hiçbir eksik yönlerinin olmadığını desteklemektedir.

Anahtar Kelimeler: Jenerik, İmatinib, Glivec, Kronik Miyeloid Lösemi

\section{INTRODUCTION}

Unsustainable drug prices in chronic myeloid leukemia (CML) and cancer may be causing harm to patients. Advocating for lower drug prices is a necessity to save the lives of patients who cannot afford them. ${ }^{1}$ The patent date of imatinib mesylate (IM) in USA has just expired in January 2015. Patent expiration dates for IM may be different in different countries/regions. For example in Canada and Europe generic IM has been approved for CML recently. ${ }^{2}$ However in Turkey, generic IM preparations are currently present. In Turkey, between original and generic molecules of TKI's there is a price difference because of the reimbursement policy. Thus, if a patient prefers original molecule, it means that the price difference has to be paid from the patient's own personal budget. The major concern for generic IM is its efficacy over the original drug, Glivec or Gleevec, although actually generics were shown to be bioequivalent in many basic studies. ${ }^{2}$ Elucidation of the non-inferiority of generic imatinib over the original molecule is important for effective clinical decision making in CML. ${ }^{3}$ The aim of this multi-center study is to assess the efficacy of generic IM over Glivec in terms of hematological, cytogenetic, and molecular responses in CML.

\section{PATIENTS AND METHODS}

This work is designed as a multicenter retrospective study. The data of 120 CML patients who were treated with generic or original form of IM, were obtained from six different hematology clinics in Turkey between the years of 2009-2014 and analyzed retrospectively. Ethical approval has been obtained from the Ethics Committee of Hacettepe Medical School. All of the ethical considerations had been strictly followed in accordance with the Helsinki declaration. The patients were evaluated at 4 different time points for the change of medication and efficacy of treatment in each center. The data of age, gender, type and dose of treatment, adverse effects of the treatment, smoking history, ECOG performance, the stage of CML at diagnosis, cytogenetic and molecular remissions and bone marrow transplantation treatment were obtained. IM response was evaluated with criteria recommended by European LeukemiaNet. ${ }^{4}$ Molecular response (MR) was decided with BCR-ABL1 gene transcript ratio that is reported as International Scale (IS). Complete hematologic response (CHR) was accepted as white blood cells $<10 \times 10^{9} / \mathrm{L}$, basophils $<5 \%$, no myelocytes, promyelocytes, myeloblasts in the differential, platelet count $<450 \times 10^{9}$ $/ \mathrm{L}$ and non-palpable spleen. Complete cytogenetic response (CCyR) was accepted as no $\mathrm{Ph}$ metaphases in cytogenetic analysis. Major molecular 


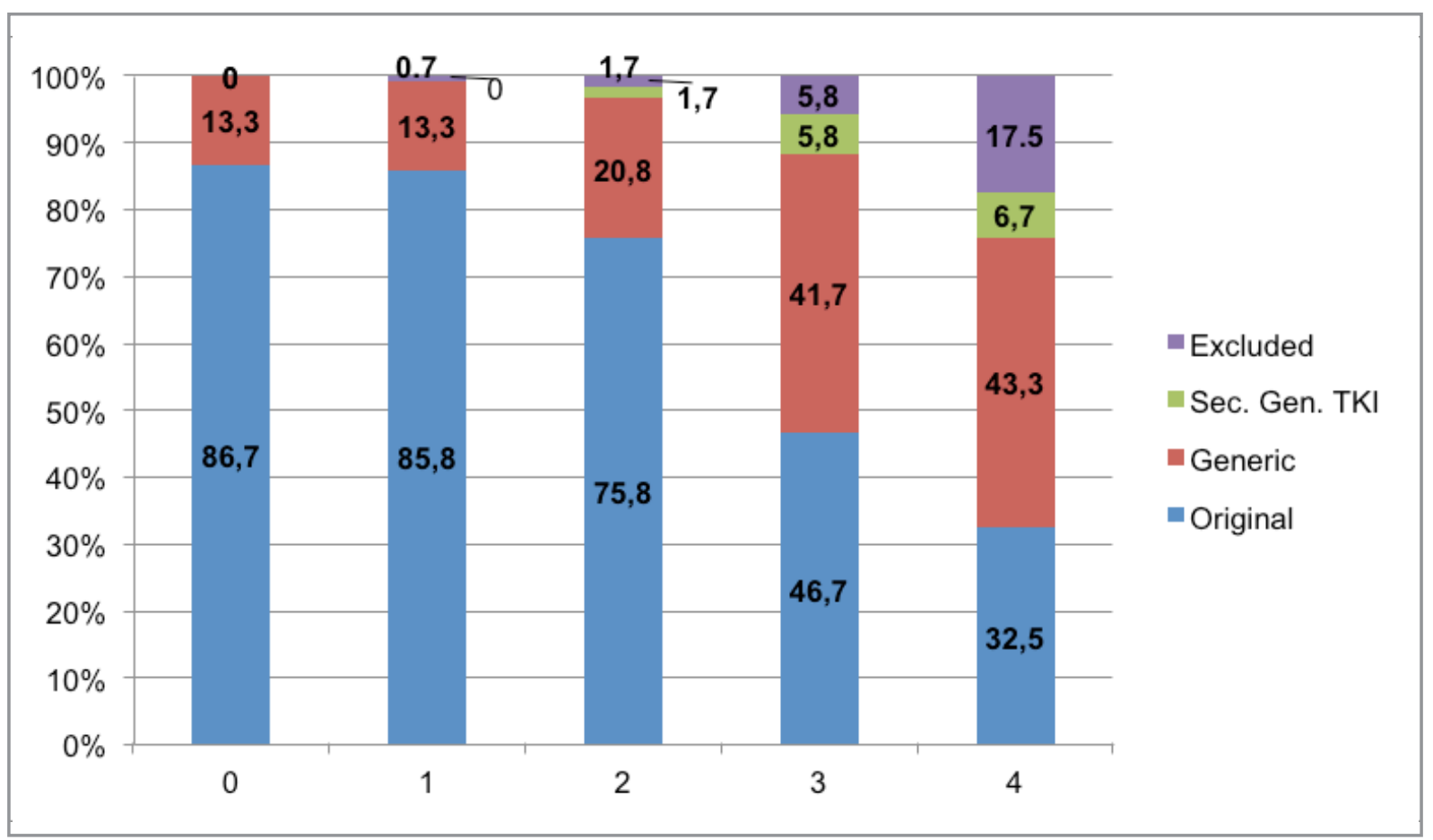

Figure 1. The ratio of drugs that were preferred by the clinicians for each evaluation.

Sec. Gen. TKI= Second Generation TKI

response is accepted as a BCR-ABL1 expression of $\leq 0.1 \%$ on the international scale. Categorical and continuous data were compared by the Chisquare (or Fisher's Exact test if required by sample size) and Independent-samples T-test, respectively. Bivariate correlation analysis for categorical variables was done by Spearman's correlation analysis. Statistical Packages for the Social Sciences v17.0 (SPSS Inc., Chicago, IL) software was used for statistical analyses.

\section{RESULTS}

There were 68 female and 52 male participants in the study. There was no difference in gender distribution of the cases between study centers. All of the patients were in chronic phase of CML at diagnosis. The median age of the participants were 53 (21-81). The number of patients in each ECOG performance score were $70 / 32 / 7 / 3 / 0$ for ECOG scores of 0/1/2/3/4 respectively. 8 patients' ECOG score was unknown. At the onset of the study 104 (86.7\%) patients were using original imatinib whereas $16(13.3 \%)$ patients were using generic imatinib molecules. The percentages of generic imatinib molecule usage in first, second, third and fourth visit were $13.3 \%, 20.8 \%, 41.7 \%$ and $43.3 \%$, respectively. The mean period between each evaluation was 9 months. Initial evaluation revealed that only one patient who was using original molecule switched to second generation TKI. In this period, hematological response (HR) was observed in $99.2 \%$ of the patients, cytogenetic response (CR) was observed in $88.7 \%$ of the patients (47 of 53), and molecular response (MR) was observed in $75 \%$ of the patients. For each evaluation, the ratio of drugs that were preferred by the clinicians is shown in Figure 1. According to Figure 1, clinicians had a tendency to prefer generic molecules in each sequent visit, and this switch rate was statistically significant $(\mathrm{p}<0.001)$. The rates of switching from original molecule to generic molecule, from original molecule to second generation TKI, and from generic molecule to second generation TKI are shown in Table 1. Accordingly, 11 patients, who were using original molecules during all cohorts, switched to second generation TKI. On the other hand, only one patient, who was using generic molecules, switched to second generation TKI (Table 1). Response to treatment is shown in 


\begin{tabular}{|c|c|c|c|c|c|c|}
\hline & \multicolumn{2}{|c|}{ Original to Generic } & \multicolumn{2}{|c|}{$\begin{array}{l}\text { Original to Second } \\
\text { Generation TKI }\end{array}$} & \multicolumn{2}{|c|}{$\begin{array}{l}\text { Generic to Second } \\
\text { Generation TKI }\end{array}$} \\
\hline & $n$ & $\%$ & $n$ & $\%$ & $\mathrm{n}$ & $\%$ \\
\hline First Visit & $1 / 103$ & 1.0 & - & - & - & - \\
\hline Second Visit & $12 / 103$ & 11.6 & $1 / 103$ & 1.0 & $1 / 17$ & 5.9 \\
\hline Third Visit & 28/91 & 30.8 & $5 / 91$ & 5.5 & - & - \\
\hline Fourth Visit & $28 / 56$ & 50.0 & $5 / 56$ & 8.9 & - & - \\
\hline
\end{tabular}

Figure 2. The ratio of CML treatment responses at the four evaluation points including hematological, cytogenetic, molecular response is shown in Figure 2. There was no statistical significant difference between original and generic molecules in terms of hematological, cytogenetic and molecular responses (Table 2).

\section{DISCUSSION}

In the literature there are studies that report the price difference between drugs are so important that it could be the only reason for changing the treatment with generic TKIs. ${ }^{5}$ Without considering the health care budget and pharmacoeconomy, it is not realistic to manage the treatment of CML since the economy is directly related with accessibility of drug for patients and penetration of drug

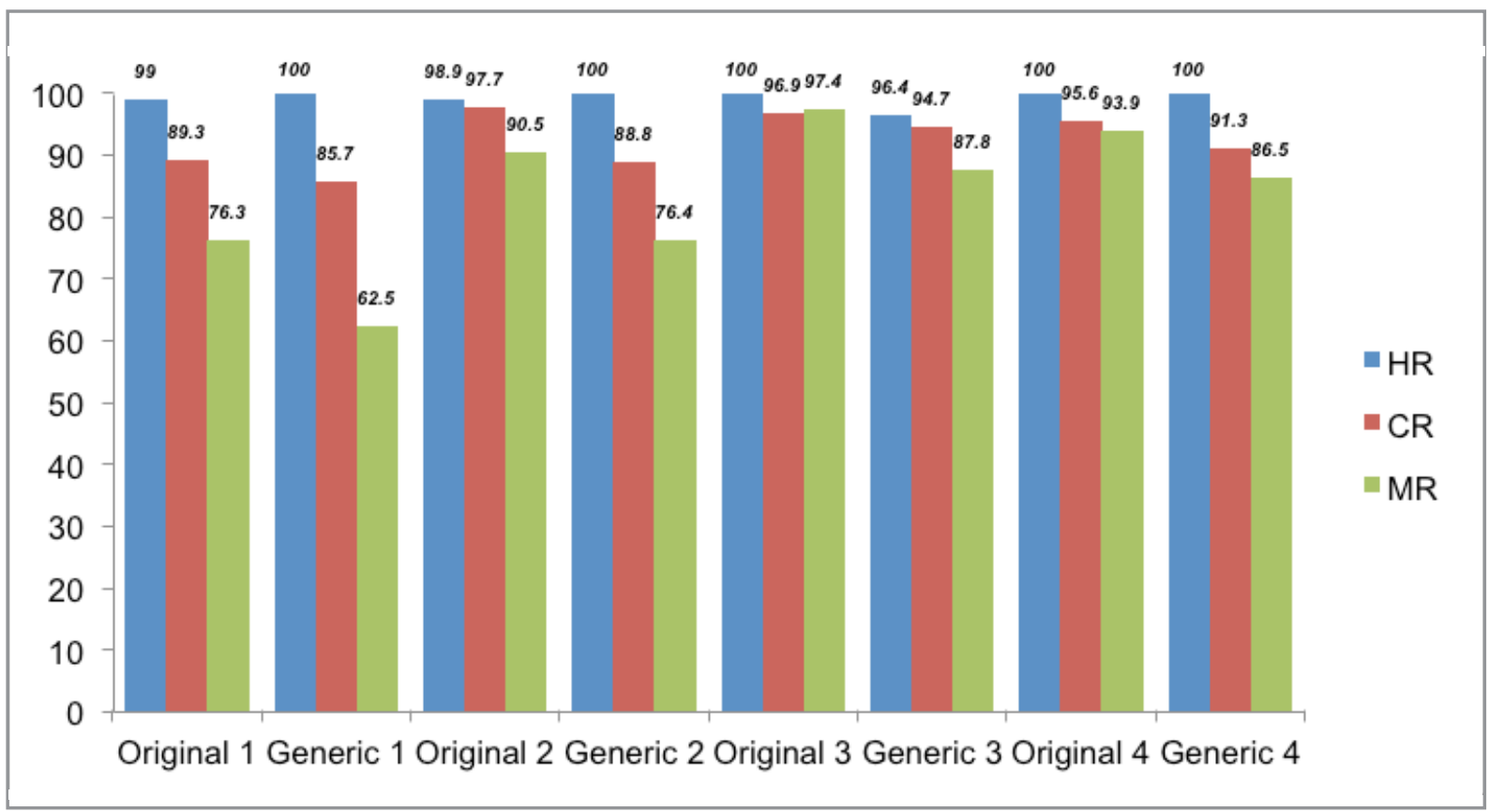

Figure 2. The ratio of CML treatment responses at the four evaluation points.

$(\mathrm{HR}=$ hematological response, $\mathrm{CR}=$ cytogenetic response, $\mathrm{MR}=$ molecular response) 


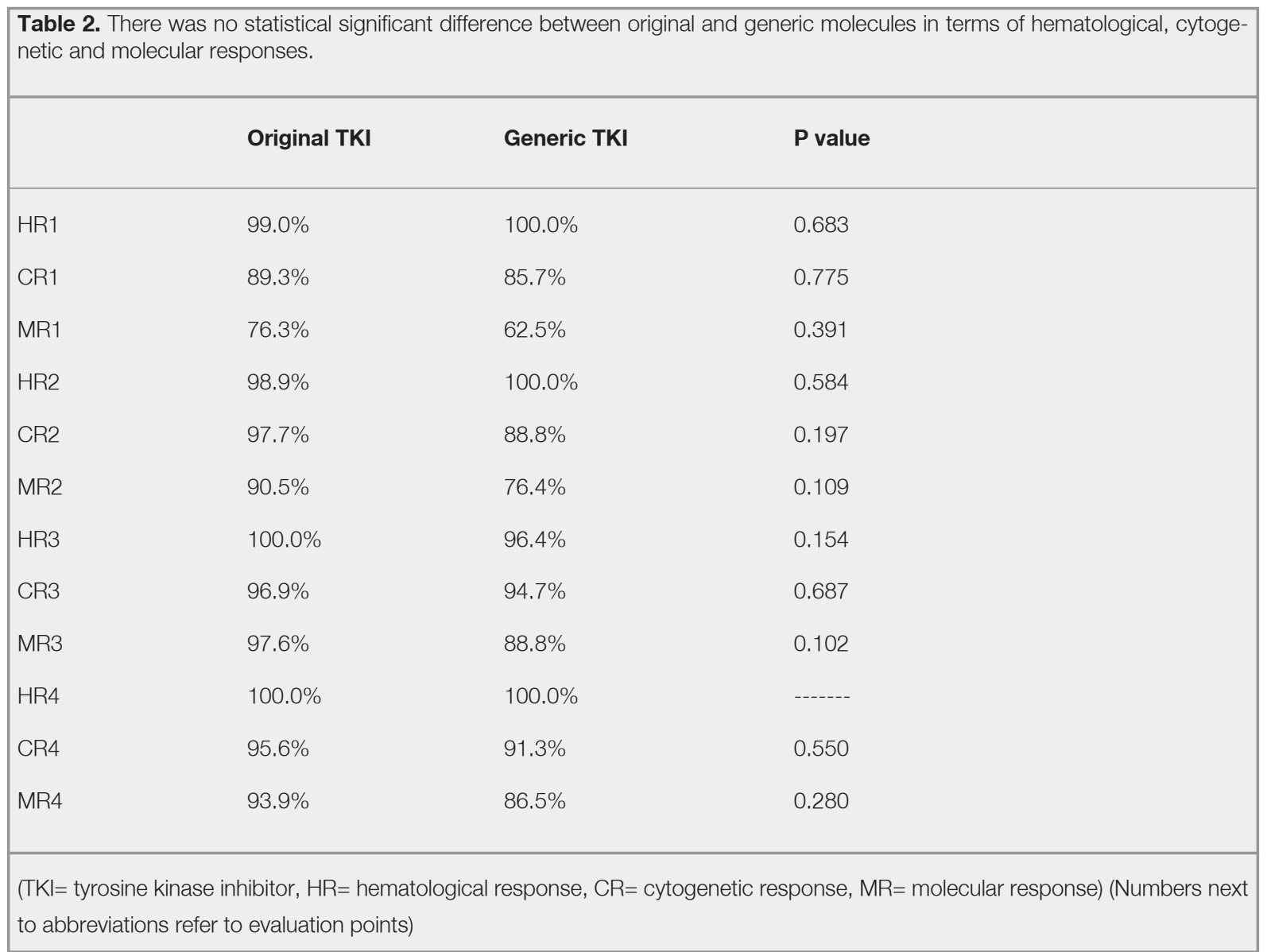

to country. By looking this point of view, generic TKIs are very important for sustainability of the treatment and offer large amounts of health care budget savings. ${ }^{6}$ In a recent paper, it is stated that the patent of Glivec will expire in the near future in many countries and already generics have resulted in cost savings in countries which generic TKIs are in the market. ${ }^{7}$ The necessity to argue the cancer drug prices for finding solutions in order to reduce them, was stated in literature. Also it is stated that in CML drug prices should not exceed values that harm patients and societies. ${ }^{8}$ Because of ongoing debates about the efficacy of generic TKIs, some CML patients in Turkey who choose to continue with original molecule still have to pay the price difference individually. This may led to problems with the continuation of treatment as well as other social problems. Patient's economic problems and healthcare policy could be the reasons of this tendency in medium/low income countries. In a recent paper, it is reported that the potential cost savings and clinical benefits of generic IM depends on not only physicians but also market forces, third-party payer and regulatory authority behavior. ${ }^{9}$ Not only the drug prices but also the efficacy and side effects of generic TKIs are concerned. There are several studies that reported generic TKIs are also well tolerated and could be safely used..$^{5}$ Conflicting data about generic TKIs efficacy and side-effects comes from relatively small number of patient cohorts and this issue have been criticized in a recently published paper. ${ }^{10}$ In the literature, there are some studies indicating the non-inferiority of generic TKIs in comparison to the original molecule. ${ }^{11-13}$ However, there are different reports about generic TKIs which make clinicians to hesitate to switch to generic form. In the literature, some authors suggested that original molecule is superior to generics. ${ }^{14,15}$ In a study which was conducted with 30 patients, generic TKI was used as first line therapy and resulted with 90\% CHR and $46.7 \%$ molecular response rate. ${ }^{16}$ On the other hand, a 
study with 126 patients resulted with lost in $33 \%$ CHR after changing the treatment to generics. ${ }^{17}$ One of the clinical limitation of the reports which suggest generic TKIs are inferior that these studies involve relatively small number of cases or they are just case reports. ${ }^{18,19}$ Moreover, some of those studies were financially supported by pharmaceutical companies. ${ }^{18,19,20}$ Furthermore it is also unclear whether the generic IM which was used in these studies was bioequivalent or not. ${ }^{21}$ Likewise, there are speculations about the different crystal forms of IM may affect its clinical efficacy. However in literature there are no reports of different clinical efficacy related to polymorphism of IM. ${ }^{2}$ Our paper may help to clarify the doubts about the efficacy of generic IM compared to original molecule. As indicated in Figure 1, there is a tendency to use generic molecules in our country. In CML, the indications for switching the treatment to the second generation TKIs are clearly stated in the literature..$^{22}$ In our study, the data in Table 1 confirms the efficacy of generic TKIs because of the low rates of need to switch to second generation TKIs during treatment. Our study contributes to literature by the data of six different centers from Turkey. Moreover, in our study we did not find any significant difference in HR, CR, and MR for original and generic drugs in each visit. In an editorial paper it is stated that, theoretically retrospective studies have limitations in different manners which confirms actually there is a need for a Phase IV study that compares generic TKIs with original forms by the manner of efficacy and safety. However unfortunately, it is very unlikely for this kind of study will be supported by the pharmaceutical companies. Therefore well-designed large-scale retrospective studies which patients diagnosed and followed with standard care of practice is the best choice to get reliable information about generic TKIs until long-term solid prospective data are available. ${ }^{6}$ From this point of view our study is important as it is a multi-center study which includes the clinical follow-ups of the CML patients.

Conclusion: The findings of our study indicated that generic IM is as effective as original Glivec in the clinical management of CML. Although this data should be confirmed especially with prospective studies, there is a huge benefit to patients as well as policy makers if the non-inferiority of generic molecules is evident. To conclude, in this study we find low rates of need to switch to second generation TKIs with generic IM and no difference in treatment responses between generic and original molecules that confirms the non-inferiority of generic TKIs over original molecules.

\section{Conflict of Interest Statement}

The authors of this paper have no conflicts of interest, including specific financial interests, relationships, and/or affiliations relevant to the subject matter or materials included.

\section{REFERENCES}

1. Abboud C, Berman E, Cohen A, et al. The price of drugs for chronic myeloid leukemia (CML) is a reflection of the unsustainable prices of cancer drugs: from the perspective of a large group of CML experts. Blood 121: 4439-4442, 2013.

2. De Lemos ML, Kyritsis V. Clinical efficacy of generic imatinib. J Oncol Pharm Pract 21: 76-79, 2015.

3. Haznedaroglu IC. Current concerns of undertreatment and overtreatment in chronic myeloid leukemia based on European LeukemiaNet 2013 recommendations. Expert Opin Pharmacother 14: 2005-2010, 2013.

4. Baccarani M, Deininger MW, Rosti G, et al. European LeukemiaNet recommendations for the management of chronic myeloid leukemia: 2013. Blood 122: 872-884, 2013.

5. Eskazan AE, Elverdi T, Yalniz FF, et al. The efficacy of generic formulations of imatinib mesylate in the treatment of chronic myeloid leukemia. Leuk Lymphoma 55: 2935-2937, 2014.

6. Soysal T, Eskazan AE, Ar MC. Generics in chronic myeloid leukemia: current arguments for and against and the established evidence. Expert Rev Hematol 7: 697-699, 2014.

7. Eskazan AE, Soysal T. The current situation and future aspects of cost-eff ectiveness in chronic myeloid leukemia treatment. Leuk Lymphoma. 56: 1554-1555, 2015.

8. Dusetzina SB, Winn AN, Abel GA, et al. Cost Sharing and Adherence to Tyrosine Kinase Inhibitors for Patients With Chronic Myeloid Leukemia. J Clin Oncol 32: 306-311, 2014.

9. Conti RM, Padula WV, Larson RA. Changing the cost of care for chronic myeloid leukemia: the availability of generic imatinib in the USA and the EU. Ann Hematol 94: 249-257, 2015. 
10. Eskazan AE, Ar MC, Soysal T. The efficacy and tolerability issue of generics of imatinib in the treatment of chronic myeloid leukemia: do generics really jeopardize patient safety? Leukemia \& Lymphoma. 56: 1182-1183, 2015.

11. Eskazan AE, Ayer M, Kantarcioglu B, et al. First line treatment of chronic phase chronic myeloid leukaemia patients with the generic formulations of imatinib mesylate. Br J Haematol. 167: 139-141, 2014.

12. Eskazan AE, Elverdi T, Yalniz FF, et al. The efficacy of generic formulations of imatinib mesylate in the treatment of chronic myeloid leukemia. Leuk Lymphoma 55: 2935-2937, 2014.

13. Eskazan AE, Soysal T. Generic imatinib in the treatment of chronic myeloid leukemia: Cerrahpasa experience. J Oncol Pharm Pract 2015 doi: 10.1177/1078155215570766.

14. Alwan AF, Matti BF, Naji AS, et al. Prospective single-center study of chronic myeloid leukemia in chronic phase: switching from branded imatinib to a copy drug and back. Leuk Lymphoma 55: 2830-2834, 2014

15. Saavedra D, Vizcarra F. Deleterious effects of non-branded versions of imatinib used for the treatment of patients with chronic myeloid leukemia in chronic phase: a case series on an escalating issue impacting patient safety. Leuk Lymphoma 55: 2813-6, 2014.

16. Razmkhah F, Razavi M, Zaker F, et al. Hematologic and molecular responses to generic imatinib in patients with chronic myeloid leukemia. Lab Med 41: 547-550, 2010.

17. Alwan A, Alshami A, Hatim A, et al. Impact of switching therapy from imatinib mesylate to generic copy of imatinib on hematologic response in patients with chronic phase chronic myeloid leukemia: single center study. Presented at the Congress of the European Hematology Association; London, United Kingdom, 11 June 2011: Abstract 1219.

18. Chouffai Z. Hematologic relapse after 2 years on a nonauthorized copy version of imatinib in a patient with chronic myeloid leukemia in chronic phase: a case report. Case Rep Oncol 3: 272-276, 2010.
19. Mattar M. Failure of copy Imatib (CIPLA, India) to maintain hematologic and cytogenetic responses in chronic myeloid leukemia in chronic phase. Int J Hematol 91: 104-106, 2010.

20. Asfour IA, Elshazly SA. Changing therapy from Glivec to a "copy" imatinib results in a worsening of chronic myeloid leukemia disease status: two case reports. Cases Journal. 2: 9342, 2009

21. Gogtay J, Chahchad S, Jadhav S, et al. Response to the case report by Mattar: Generic Imatinib (Imatib, Cipla) in a patient with chronic myeloid leukemia in chronic phase. Int $\mathrm{J}$ Hematol 92: 772-773, 2010.

22. Buyukasik Y. Use of second generation tyrosine kinase inhibitors for second-line treatment of chronic myeloid leukemia after imatinib failure. UHOD 21[Suppl 1]: 4-9, 2011.

\section{Correspondence}

Dr. Ümit Yavuz MALKAN

Hacettepe Üniversitesi Tip Fakültesi

Hematoloji Anabilim Dali

Sihhiye, ANKARA / TURKEY

Tel: (+90-532) 7780087

Fax: (+90-312) 3051614

e-mail: umitmalkan@hotmail.com 